\title{
Financial Literacy Level of Individuals and Its Relationships to Demographic Variables
}

\author{
Murat Yıldırım ${ }^{1}$ \\ Fatih Bayram ${ }^{2}$ \\ Ahmet Oğuz ${ }^{3}$ \\ Gülay Günay ${ }^{4}$ \\ ${ }^{1}$ Karabuk University, Department of Business, Karabuk/Turkey \\ ${ }^{2}$ Karabuk University, Department of Public Relations and Publicity, Karabuk/Turkey \\ ${ }^{3}$ Karabuk University, Department of Economics, Karabuk/Turkey \\ ${ }^{4}$ Karabuk University, Department of Social Work, Karabuk/Turkey
}

\section{Doi:10.5901/mjss.2017.v8n3p19}

\section{Abstract}

Families act in an environment of financing system which includes the pressure of the economic powers. Under these economic conditions, standards of living of individuals who fail to take optimal financial decisions and to exhibit due financial behaviors undergo some change. Individuals' self-consciousness on financial issues will not only prepare them for prospective hard economic conditions that may emerge in the future but also supports the development of the country on strong basis. In this perspective, the awareness of financial literacy will help to use the limited sources more affectively. Recently in this economic pressure financial literacy has become an increasingly important topic. The main purpose of this study is examining individual's financial literacy level and determining the relationship between demographic variables and financial literacy. Participants in the study consist of individual who are employees in iron and steel industry and dwelling in Karabuk, Turkey. A total of 304 employees are participated in the study on a voluntary basis. Data were collected through a demographic information form, Financial Literacy Index developed by Van Rooji et al. (2011). Financial Literacy Index includes two sections: basic financial literacy (5 items) and advantage financial literacy (11 items). Results indicated that only $8.9 \%$ of the participants have correctly answered the five basic financial literacy items. The proportion of the correct answered in advantage financial literacy section (11 items) was too low (0.3\%). The statistical analyses displayed that from demographic variables only education and monthly income was important determinant, both of basic and advantage financial literacy $(p<0.05)$. The results of this research have significant implications for individuals, policymakers and educators in their search of strategies for improving individuals' financial literacy level.

Keywords: finance, financial literacy, financial knowledge, knowledge of economics, personal finance,

\section{Introduction}

Today individuals live in a financial system that is under the pressure of such economic powers as changing economic balances, higher unemployment rates, changes in purchasing power, inflation, increased tax burden, changing government policies, instable interest rates, complexification of the consumer market and increasing competition among businesses (Hung et al. 2009; Terzioğlu,1990; Sumarwan \& Hira,1992; Bailey,1987). In this environment, individuals' behaviors concerning the use of their financial resources affect not only their own social and economic well-being but also the national economy (Çopur \& Şafak, 2003). In an environment of ever-changing conditions, in order for individuals and families to have ideal and quality living conditions they should first reach decent living standards (Özmete, 2004). Therefore, today, financial management skills of individuals are the most important source for increasing and improving their well-being (Raijas, 2011). Accordingly, it is necessary that income expenditure is planned for both the present and the future and that consumption, saving and investment should be balanced efficiently in order to enhance the quality of life and economic development. 
In an environment in which economic life is constantly changing and evolving into a more complex structure, financial problems individuals face are also diversified. Under these economic conditions, standards of living of individuals who fail to take optimal financial decisions and to exhibit due financial behaviors undergo some change. This also increases the level of economic anxiety among individuals (Hung et al. 2009; Temizel \& Bayram, 2011). In addition, changes in the overall economic conditions of countries, labor markets and the social structure make the importance of financial literacy even more clear (Bayram, 2010).

Financial literacy has become an increasingly common term in economic and financial studies. Definitions vary depending on the study field, expertise and field of interest of the person who formulates the definition. In a comprehensive literature review conducted by Huston (2010), it has been revealed that 71 studies attempt to define the concept of financial literacy and that the term has been assigned eight different meanings. Some studies handle financial literacy completely within the context of general knowledge on financial issues while others emphasize the multidimensional nature of financial literacy, both the knowledge and experience related aspects, the ability to be selfconfident when making financial decisions and the competence to make financial decisions. According to PACFL (President's Advisory Council on Financial Literature, 2008), "financial literacy" is "individuals' ability to use and manage financial resources effectively and to use knowledge and skills to ensure a lifetime financial well-being.

Particularly in the last 20 years, the fact that financial markets have grown and got more complex due to globalization and that financial instruments have been diversified have increased the importance of financial literacy in the developed and developing countries. It depends on individuals' ability to increase their levels of financial literacy to avoid financial damages in their financial decisions (Bayram, 2010).

Many individuals are not able to do economic calculations or to understand the distinction between nominal and real value. They also do not have sufficient knowledge about such basic economic terms as basic risk diversification. In addition, they also need to be informed about such complicated concepts as the differences between bonds and stocks, investment fund operations and primary asset pricing comparisons (Lusardi \& Mitchell, 2014; Lusardi, 2008). A range of studies into the issue have revealed that those who lack sufficient financial knowledge are not able to save duly for their retirement (Lusardi \& Mitchell, 2007), use high-interest loans and experience debt problems (Moore, 2003), follow the financial advice of their family and friends and invest less in stocks (Van Rooij et al. 2011). Therefore, individuals require education in relation to a range of financial issues to meet their financial needs and increase their wealth (Gale \& Levine, 2010, Lusardi \& Mitchell, 2014).

As a consequence, it has been emphasized in various studies that individuals who are competent enough in terms of financial literacy have better financial decision making skills than do those who lack this competence. It has also been indicated that competent individuals are also more successful in financial planning and investment (Van Rooij et al. 2011; Bernheim \& Garrett, 2003; Lusardi \& Mitchell, 2007; Hilgert et al. 2003; Sevim et al. 2012; Temizel, 2010). The aim of the 86 present study is to investigate the levels of financial literacy of employees who working in iron and steel industry.

\section{Method}

\subsection{Participation}

The study population was composed of the employees of Kardemir Inc. The personnel list supplied by the Human Resources Department of Kardemir Inc., which included all the employees from all the departments, was utilized when defining the population. According to the figures from November 2016, Kardemir Inc. offers employment to 3924 people (Kardemir, 2016). Only volunteers were included in the study population and accordingly, the study reached 350 employees.

Interviews were made with the Human Resources Department of Kardemir Inc. before collecting the study data. Besides, necessary permissions were taken from the business for conducting the study questionnaire. Participants were informed about the purpose of the study and about how to complete the questionnaire. After answering their questions, those who volunteered to participate were included in the study. 350 employees completed the questionnaire form. However, only 304 questionnaire forms were included in the study since some (a total of 46 questionnaire forms) questionnaires were incorrectly completed or returned incomplete. Study data were collected in the company premises at the authorized dates in January 2017.

\subsection{Instruments}

The questionnaire form was prepared by the researchers in accordance with the relevant literature (Van Rooij et al. 2011; Lusardi \& Mitchell, 2007; Lusardi \& Mitchell, 2014). It was short and precise so that participants did not lose interest or got 
tired. The questionnaire is composed of two sections namely demographical information section and financial literacy index.

Demographical Information Form: This section contains demographical questions aimed to identify gender, age, educational attainment and monthly income.

Financial Literacy Index: Financial Literacy Index developed by Van Rooji et al. (2011) was utilized to define the financial literacy levels of the participants. This index handles financial literacy levels of individuals in two categories namely basic financial literacy and advanced financial literacy. The questions are responded by participants without help and without doing any calculations. The basic category consists of 5 questions on the ability to calculate simple interest, how compound interest works, inflation, knowledge of the time value of money, money illusion (is the situation in which individuals takes the nominal value of money into consideration instead of its real value). Possible responses to the questions are 'true', 'false' and 'do not know'. Advanced financial literacy category, on the other hand, comprises 11 questions on a range of subjects that include bonds and stocks in financial markets of different development levels as well.

\subsection{Data Analysis}

Research data were analyzed via statistical methods. Accordingly, the data were analyzed using the SPSS (Statistical Package for the Social Sciences) software package version 18.0. In the first place, frequency and percentages were calculated in order to analyze the demographics and financial literacy levels of the participants.

The non-parametric Kruskal-Wallis $\mathrm{H}$ Test was used because of the variables was categorical. Statistical significance was taken at the $5 \%$ level (Büyüköztürk, 2007:146-166).

For the differences between basic and advances financial literacy level and demographic variables (age, education and monthly income) the non-parametric Kruskal-Wallis H Test was used. In the event that the comparison of three or more population groups is aimed at, where data are ordinal measured, then for the statistical significance of differences Kruskal-Wallis $\mathrm{H}$ test is used. Kruskal - Wallis $\mathrm{H}$ test is the non-parametric counterpart of the one way ANOVA (Büyüköztürk, 2007:158).

\section{Results}

$95.1 \%$ of the participants were male and $4.9 \%$ were female. The rate of male participants is seen to be higher than that of female ones. This is caused by the fact that, in the population from which the sample has been taken, woman labour is benefited less in iron and steel sector, described as heavy industry. Hence, the rate of women working in industrial sector is only $16.1 \%$ based on the data of Household Labour Force Survey (2014) conducted by the Turkish Statistical Institute (TSI, 2010).

Ages of the participants ranged from 21 to 57 and the average age was calculated to be 39 (S=6.8). Nearly half of the participants (49.3\%) were between $33-44$ years of age. As to educational attainment, those who reported being high school graduates corresponded to the highest proportion $(51.0 \%)$ and they were followed by those with university or postgraduate degrees $(35.9 \%)$ and primary school graduates (13.2\%). The average household income was TRY 3182.2 ( $S=1437.5$ ) and the levels of monthly income varied between TRY 1000 and TRY 10000. 39.8\% of the employees were included in the income group "TRY 3001 or higher", 36.2\% were in the group "between TRY 2001 and 3000", and finally $24 \%$ of the participants were in the group "TRY 2000 or lower" (Table 1).

Table 1. Demographic Variables

\begin{tabular}{lcc}
\hline Demographic variables & F & $\%$ \\
\hline Gender & 15 & 4,9 \\
Female & 289 & 95,1 \\
Male & & \\
Age (M=39.1; S=6.8) & 100 & 32,9 \\
Less than 32 & 150 & 49,3 \\
33 - 44 & 54 & 17,8 \\
More than 45 & & \\
Education & 40 & 13,2 \\
Primary school (8 years) & 155 & 51,0 \\
High school (11 years) & 109 & 35,9 \\
Bachelor's (15 years and more) & & \\
Monthly family income & 73 & 24,0 \\
Low (Less than 2000 TL) & 110 & 36,2 \\
Middle (2001 TL - 3000 TL) & 121 & 39,8 \\
High (More than 3001 TL) & & \\
\hline
\end{tabular}


The basic financial literacy index (Van Rooij et al. 2011) consists of 5 questions aimed to measure participants' knowledge about calculation of simple interest, how compound interest works, inflation, knowledge of the time value of money, money illusion. Responses to these questions are presented in Table 2. More than half of the employees (54.3\%) answered the question on basic mathematics skills, more clearly the one on basic interest calculation, correctly. The question on how compound interest works were answered correctly by the $37.8 \%$ of the participants. The proportion of those who gave correct answer to the question on inflation was $30.6 \%$ while the percentage of those who provided correct answer to the question on knowledge of the time value of money was $37.5 \%$. Finally, the last question of the basic financial literacy index namely the question on money illusion was answered correctly by the $37.2 \%$ of the participants (Table 2).

Table 2. Basic Financial Literacy

\begin{tabular}{lcccccccccc}
\hline Basic Financial Literacy & \multicolumn{2}{c}{ Numeracy } & \multicolumn{2}{c}{ Interest compounding } & \multicolumn{3}{c}{ Inflation } & \multicolumn{2}{c}{ Time value of money } & \multicolumn{2}{c}{ Money illusion } \\
\cline { 2 - 11 } & $\mathbf{F}$ & $\%$ & $\mathbf{F}$ & $\%$ & $\mathbf{F}$ & $\%$ & $\mathbf{F}$ & $\%$ & $\mathbf{F}$ & $\%$ \\
\hline True & 165 & 54,3 & 115 & 37,8 & 93 & 30,6 & 114 & 37,5 & 84 & 27,6 \\
False & 18 & 5,9 & 62 & 20,4 & 59 & 19,4 & 66 & 21,7 & 113 & 37,2 \\
Do not know & 121 & 39,8 & 127 & 41,8 & 152 & 50,0 & 124 & 40,8 & 107 & 35,2 \\
\hline
\end{tabular}

Mathematical weights for the responses to the 5 five questions directed in the basic financial literacy index (true, false or do not know) were calculated one by one and are presented in Table 3. According to Table 3, the majority of the participants responded each basic financial literacy question correctly, yet the proportion of the participants who provided the correct answer to all five questions was $8.9 \%$. This result indicates that the participants did not have sufficient knowledge in the areas of basic financial literacy.

Table 3. Weights of the Responses to Basic Financial Literacy Questions (True, False, Do not know)

\begin{tabular}{lcccccccc}
\hline & \multicolumn{8}{c}{ Number of correct, incorrect, and do not know answers (out of five questions) } \\
\cline { 2 - 9 } & None & $\mathbf{1}$ & $\mathbf{2}$ & $\mathbf{3}$ & $\mathbf{4}$ & All & Mean & S \\
\hline True & 32,9 & 13,2 & 16,4 & 17,1 & 11,5 & 8,9 & 1,88 & 1,69 \\
False & 42,7 & 25,0 & 20,1 & 9,2 & 3.0 & - & 2,08 & 2,03 \\
Do not know & 37,5 & 12,5 & 8,9 & 9,2 & 9,9 & 22,0 & 1,05 & 1,13 \\
\hline
\end{tabular}

The relationship between weights of the responses to basic financial literacy questions and age $\left(X^{2}=2.335 ; d f=2 ; p>05\right)$ was statistically not important. But the relationship between weights of the responses to basic financial literacy questions and education $\left(X^{2}=29.743 ; d f=2 ; p<.05\right)$ and monthly family income $\left(X^{2}=15.458 ; d f=2 ; p<.05\right)$ statistically creating a significant differences. In this study considering the results it can be said that if the employee's education and families' monthly income level increases, the basic financial literacy level also increases (Table 4).

Table 4. Statistical Analysis of Weights of the Responses to Basic Financial Literacy Questions

\begin{tabular}{|c|c|c|c|c|c|}
\hline Demographic Variables & $\mathrm{n}$ & Mean Rank & $\mathrm{X}^{2}$ & df & $\bar{p}$ \\
\hline \multicolumn{6}{|l|}{ Age } \\
\hline Less than 32 & 100 & 163,12 & & & \\
\hline $33-44$ & 150 & 146,50 & 2.335 & 2 & .311 \\
\hline More than 45 & 54 & 149,50 & & & \\
\hline \multicolumn{6}{|l|}{ Education } \\
\hline Primary school (8 years) & 40 & 88,59 & & & \\
\hline High school (11 years) & 155 & 153,20 & 29.743 & 2 & $.000^{*}$ \\
\hline Bachelor's ( 15 years and more) & 109 & 174,95 & & & \\
\hline \multicolumn{6}{|l|}{ Monthly family income } \\
\hline Low (Less than 2000 TL) & 73 & 126,77 & & & \\
\hline Middle (2001 TL - $3000 \mathrm{TL})$ & 110 & 145,21 & 15.458 & 2 & $.000^{*}$ \\
\hline High (More than $3001 \mathrm{TL}$ ) & 121 & 174,65 & & & \\
\hline
\end{tabular}


Questions in the advanced financial literacy index have a more complex structure than the basic financial literacy index. The aim of the questions in this index is to measure the advanced financial literacy levels of individuals in relation to investment and portfolio choices. The questions explore the returns and risks of various assets and the working of the stock market in addition to such financial assets as bonds and investment funds. Besides, the questions also measure individuals' financial knowledge about risk diversification, working of investments funds, the relationship between interest rates and bond prices.

The pattern of the responses to the advanced financial literacy index was highly different from that of the basic financial literacy level index. The proportion of those thinking that the risk of losing money will fall if an investor spreads their money among different investment instruments (42.8\%) turned out to be equal to that of those thinking that if one buys the stocks of the company B, they will own some part of that company. A little more than one-third of the employees' (35.5\%) were correct about the fact that bond prices will vary in accordance with interest rates. However, the proportion of those who admitted not being knowledgeable about how bonds work (questions no 9, 13, 14 and 16) was high (Table 4). The proportion of those who knew that in the long-run, stocks as an investment instrument will offer the highest profit was $27.6 \%$. Those who indicated that purchasing the bond of a company means lending some money to the subject company and that stocks are more risky than bonds constituted the 15.5 percent of the participants while the proportion of those who reported not being knowledgeable about this fact was $63.2 \%$. Furthermore, more than half of the participants $(58.2 \%)$ were understood to lack knowledge about the main function of the capital market or the assets with highest price fluctuations. $18.4 \%$ said their investment funds might invest in a variety of assets such as stocks and bonds while $17.4 \%$ of them knew that purchasing stocks from investment funds offer safer returns than do purchasing stocks direct from companies (Table 4).

Table 5. Advanced Financial Literacy

\begin{tabular}{|c|c|c|c|c|c|c|}
\hline \multirow[t]{2}{*}{ Advanced Financial Literacy } & \multicolumn{2}{|c|}{ True } & \multicolumn{2}{|c|}{ False } & \multicolumn{2}{|c|}{ Do not know } \\
\hline & $\mathbf{F}$ & $\%$ & F & $\%$ & F & $\%$ \\
\hline Which statement describes the main function of the stock market? & 49 & 16,1 & 78 & 25,7 & 177 & 58,2 \\
\hline What happens if somebody buys the stock of firm B in the stock market? & 130 & 42,8 & 39 & 12,8 & 135 & 44,4 \\
\hline Which statement about mutual funds is correct? & 56 & 18,4 & 50 & 16,4 & 198 & 65,1 \\
\hline What happens if somebody buys a bond of firm B? & 47 & 15,5 & 65 & 21,4 & 192 & 63,2 \\
\hline $\begin{array}{l}\text { Considering a long time period (for example } 10 \text { or } 20 \text { years), which asset normally } \\
\text { gives the highest return: savings accounts, bonds, or stocks? }\end{array}$ & 84 & 27,6 & 113 & 37,2 & 107 & 35,2 \\
\hline $\begin{array}{l}\text { Normally, which asset displays the highest fluctuations over time: savings accounts, } \\
\text { bonds, or stocks? }\end{array}$ & 49 & 16,1 & 78 & 25,7 & 177 & 58,2 \\
\hline $\begin{array}{l}\text { When an investor spreads his money among different assets, does the risk of losing } \\
\text { money increase, decrease, or stay the same? }\end{array}$ & 130 & 42,8 & 39 & 12,8 & 135 & 44,4 \\
\hline $\begin{array}{l}\text { If you buy a } 10 \text {-year bond, it means you cannot sell it after } 5 \text { years without incurring a } \\
\text { major penalty. True or false? }\end{array}$ & 56 & 18,4 & 50 & 16,4 & 198 & 65,1 \\
\hline Stocks are normally riskier than bonds. True or false? & 47 & 15,5 & 65 & 21,4 & 192 & 63,2 \\
\hline $\begin{array}{l}\text { Buying a company fund usually provides a safer return than a stock mutual fund. } \\
\text { True or false? }\end{array}$ & 53 & 17,4 & 75 & 24,7 & 176 & 57,9 \\
\hline $\begin{array}{l}\text { If the interest rate falls, what should happen to bond prices: rise/fall/stay the } \\
\text { same/none of the above? }\end{array}$ & 108 & 35,5 & 32 & 10,5 & 164 & 53,9 \\
\hline
\end{tabular}

It turned out that only one out of 304 participants $(0.3 \%)$ responded all the advanced financial literacy questions (11 questions) correctly. The percentage of those who admitted they did not know the answers was quite high. The findings of the present study are consistent with those of the studies conducted by such researchers as Temizel (2010), Sevim et al. (2012), Güler (2015), Lusardi (2008), Wagner (2015). The proportion of those who gave incorrect answer to only one question out of the 11 advanced financial literacy index questions was $47.7 \%$. One-third of the participants (31.3\%) stated they did not know the answers to the 10 of the 11 questions. These results indicate that individuals need to be informed about financial instruments. 
Table 6. Weights of the Responses to Advanced Financial Literacy Questions (True, False, Do not know)

\begin{tabular}{lcccccccccccccc}
\hline & \multicolumn{1}{c}{ Number of correct, incorrect, and do not know answers (out of eleven questions) } \\
\cline { 2 - 17 } & None & $\mathbf{1}$ & $\mathbf{2}$ & $\mathbf{3}$ & $\mathbf{4}$ & $\mathbf{5}$ & $\mathbf{6}$ & $\mathbf{7}$ & $\mathbf{8}$ & $\mathbf{9}$ & $\mathbf{1 0}$ & All & Mean & S \\
\hline Correct & 33,6 & 9,5 & 11,8 & 7,2 & 10,9 & 8,9 & 5,3 & 3,6 & 4,3 & 4,3 & 0,3 & 0,3 & 2.79 & 2.83 \\
Incorrect & 8,2 & 47,7 & 16,4 & 9,9 & 3,9 & 8,9 & 3,0 & 1,6 &, 3 & - & - & - & 2.02 & 1.70 \\
Do not know & 10,9 & 9,5 & 4,3 & 7,6 & 4,9 & 6,9 & 5,9 & 6,9 & 3,9 & 7,2 & 31,3 & 0,7 & 5.95 & 3.74 \\
\hline
\end{tabular}

The facts that whether there is a difference among the demographical characteristics of the participants such as age, educational level and family monthly income and the weights of the responses to advances financial literacy have been analyzed by means of Kruskal Wallis H-Test for Independent Samples statistically. The results displayed that the relationship between the age of employees and advanced financial literacy is not statistically significant $\left(X^{2}=0.357\right.$; $d f=2$; $p>0.05)$. Besides this, it was found that there was a statistically significant relationship between the level of education $\left(X^{2}=11.402 ; d f=2 ; p<0.05\right)$ and family monthly income levels of workers $\left(X^{2}=8.023 ; d f=2 ; p<0.05\right)$ and the weights of the responses to advances financial literacy. It can be conclude that the level of education and income of the individual has a positive effect on the level of advanced financial literacy.

Table 7. Statistical Analysis of Weights of the Responses to Advances Financial Literacy Questions

\begin{tabular}{|c|c|c|c|c|c|}
\hline Demographic Variables & $\mathbf{n}$ & Mean Rank & $X^{2}$ & $\mathrm{df}$ & $\mathrm{p}$ \\
\hline \multicolumn{6}{|l|}{ Age } \\
\hline Less than 32 & 100 & 153,18 & & & \\
\hline $33-44$ & 150 & 154,30 & .357 & 2 & .837 \\
\hline More than 45 & 54 & 146,25 & & & \\
\hline \multicolumn{6}{|l|}{ Education } \\
\hline Primary school (8 years) & 40 & 111,50 & & & \\
\hline High school (11 years) & 155 & 154,43 & 11.402 & 2 & .003 \\
\hline Bachelor's ( 15 years and more) & 109 & 164,80 & & & \\
\hline \multicolumn{6}{|l|}{ Monthly family income } \\
\hline Low (Less than $2000 \mathrm{TL}$ ) & 73 & 131,98 & & & \\
\hline Middle ( $2001 \mathrm{TL}-3000 \mathrm{TL})$ & 110 & 149,50 & 8.023 & 2 & .018 \\
\hline High (More than $3001 \mathrm{TL}$ ) & 121 & 167,60 & & & \\
\hline
\end{tabular}

\section{Conclusion}

Financial literacy is defined as the level of competence to make educated assessments for using and managing money and to make efficient and rational decisions in selecting the financial instruments that will shape investments. The present study aims to identify the financial literacy levels of individuals employed at Kardemir Inc. The Financial Literacy Index developed by Van Rooji et al. (2011) has been utilized for this purpose. This index handles financial literacy levels in two categories namely basic financial literacy and advanced financial literacy.

Findings of the present study have revealed that basic $(8.9 \%)$ and advanced $(0.3 \%)$ financial literacy levels of the employees are low. The fact that employee's knowledge on stocks and risk diversification is high is a notable finding.

According to the agreement dated 30.03.1995, for a nominal price of TRY 1, Kardemir Inc. was handed over to Kardemir Inc. in a way that $35 \%$ of the shares belonged to the employees, $40 \%$ to the local chambers of industry and craftsman's associations and the remaining $25 \%$ to the local community and the retired employees of the company. According to the agreement signed by the Privatization Administration and Kardemir Inc., it was undertaken that the shareholding structure was to be organized in accordance with the groups and percentages of shares in a way that ensured high level of participation. Accordingly, the company turned into a company with 12780 partners after the public offerings between July 7 and 14, 1995. The interest in stocks and stock market increased as Kardemir Inc. was an important company both for Turkey and Karabük and the value of the stocks the employees had then had been multiplied by 11 times by the end of 1996 .

Since its foundation, Kardemir has contributed both to the Turkish economy and to the economic, social and cultural development of Karabük. As it has contributed to the construction, assembly and launching of many industrial companies, it has been called "the company that launches companies." Kardemir has not only contributed to the 
foundation of other companies, it has also helped these companies develop an organizational culture. Kardemir has served as a school which cumulated knowledge at times of its foundation and operation and then offered this knowledge for the benefit of its employees and other small enterprises.

Basic financial literacy areas which require some basic but technical calculations are not common areas of knowledge that Kardemir Inc. employees need to employ in their daily lives. Therefore, employees' basic financial literacy levels were found to be low. Nevertheless, employees' levels of knowledge in relation to stock and risk diversification, which are advanced financial literacy areas, turned out to be high. This can be explained by the fact that Kardemir Inc. was privatized and was able to transfer its knowledge. It can be argued that employees of Kardemir Inc. have gained some advanced financial knowledge through experiential learning and cultural transmission and have shared it with each other.

In addition, the results of this study show that demographic variable such as education and monthly income level have affected financial literacy. As the education level and monthly income level higher both of basic financial literacy and advanced literacy level increased. In the literature numerous studies have focused on the relationship among demographic variables and financial literacy (Lusardi et al. 2014; Mahdavi \& Horton, 2012; Shim et al. 2009, Hung et al. 2009; Bagić 2011; Knoll \& Houts, 2012; Hilgert \& Hogarth, 2002; Lusardi \& Mitchell, 2007).

These findings make an important point for academicians, politicians, financial advisors and educators Training programs and activities are of great importance in ensuring that individuals and the society understand the strategic importance of the concept of financial literacy. Therefore, the media should be actively involved in order to raise general public awareness regarding the subject.

The process of increasing financial literacy involves many steps. Within this context, individuals and organizations should be encouraged to form basic financial consciousness. The ability to manage budgets and hence to manage spending/debts is required in order to ensure economic balance and to transform financial education into financial consciousness. Along with this, it is expected that individuals' and societies' capacity to pay debts/loans will develop and this capacity, in return, will bring about financial behaviors that can be benefited duly for a wealthier future. Thus, individuals and organizations who know how to benefit from financial opportunities will be more confident about the future. Offering financial education at all levels of social life, to all segments of the society and at all times and considering it as the $A B C$ of finance will bring a more prosperous country.

Enhancement of the financial literacy of individuals can decrease financial exclusion and facilitate individuals' access to financial markets. Using personal income for purposes other than spending can create resources for investment and savings. Increased levels of financial literacy may help preserving and sustaining a certain level of wellbeing not only during active working life but also during retirement life.

\section{Reference}

Bagić, D. (2011), Financial Literacy in Bosnia and Herzegovina: Analytical Report. Prepared for World Bank [Online] Available: https://openknowledge.worldbank.org/handle/10986/25901 (December 22,2017)

Bailey, A.W. (1987). Social and economic factors affecting the financial welfare of families. Journal of Home Economics, $79(2), 14-18$.

Bayram, S.S. (2010). Finansal okur yazarlik ve para yönetimi davranişlari: anadolu üniversitesi öğrencileri üzerine uygulama (Financial literacy and money management behaviours: application on students of Anadolu University, Unpublished Master Thesis, Eskişehir: Anadolu University Social Science Institute.

Bernheim, D. \& Garrett, D. (2003). The effects of financial education in the workplace: evidence from a survey of households. Journal of Public Economics 87,1487-1519.

Büyüköztürk, Ş., (2007). Sosyal Bilimler İçin Veri Analiz El Kitabı (Handbook for the Social Sciences Data Analysis). Pegem Akademi Yayıncilık Ankara, Baran Ofset.

Çopur, Z. \& Şafak, Ş. (2003). Ailede gelirin kullanimina ilişkin karşilaşilan problemlerin incelenmesi (Examine the problems on using of the income in the families). Aile ve Toplum (Family and Society Journal), 5(2),7 - 14.

Gale, W.G. \& Levine, R. (2011). Financial literacy: what works? how could it be more effective? Financial Security Project Working Paper 2011-1. [Online] Available: http://www.rand.org/content/dam/rand/www/external/events/2010/11/18/financial-literacy-whatworks.pdf (January 02, 2017)

Güler, E. (2015). Hane halkının finansal okuryazarlik düzeyinin belirlenmesi üzerine bir araştirma: sakarya ili örneği (A Research on determining financial literacy level of household: the case of city of Sakarya). Sakarya University Institute of Social Science, Unpublished Master Thesis, Sakarya

Hilgert, M., Hogarth, J. \& Beverly, S. (2003). Household financial management: the connection between knowledge and behavior. Federal Reserve Bulletin, July, 309-322

Hung, A. A., Parker, A.M. \& Yong, J. K. (2009). Defining and measuring financial literacy. Working Papers WR-708. RAND Corporation. [Online] Available: http://www.nber.org/papers/w16740. (January 12, 2017). 
Huston, S.J. (2010). Measuring financial literacy. The Journal of Consumer Affairs, 44(2),296 - 316.

Kardemir Inc. (2016). Human Resources. [Online] Available: https://www.kardemir.com/Info.aspx?Sec=Bilgi\&Lng=tr-TR\&W=1 (January 02, 2017).

Knoll, M.A.Z \& Houts, C.R. (2012). The Financial knowledge scale: An application of item response theory to the assessment of financial literacy. The Journal of Consumer Affairs, 46(3), 381-410.

Lusardi, A. (2008). Financial literacy: an essential tool for informed consumer choice?", CFS Working Paper, No. 2008/19, [Online] Available: http://nbn-resolving.de/urn:nbn:de:hebis:30-56927. (February 05, 2017).

Lusardi, A. \& Mitchell, O. S. (2014). The economic importance of financial literacy: theory and evidence. Forthcoming Journal of Economic Literature, 52(1),5 - 44.

Lusardi, A., Mitchell, O. S., \& Curto, V. (2014). Financial literacy and financial sophistication in the older population. Journal of Pension Economics and Finance, 13(04), 347-366.

Lusardi, A. \& Mitchell, O.S. (2007). Financial literacy and retirement preparedness: evidence and implications for financial education. Business Economics, 42, 35-44.

Mahdavi, M., \& Horton, N. (2014). Financial literacy among educated women: room for improvement. Journal of Consumer Affairs, 48(2);403- 417.

Moore, D. (2003). Survey of financial literacy in washington state: knowledge, behavior, attitudes and experiences, Technical Report 0339. Social and Economic Sciences Research Center, Washington State University. [Online] Available: https://www.researchgate.net/publication/265728242_Survey_of_Financial_Literacy_in_Washington_State_Knowledge_behavior Attitudes_and_Experiences (February 05, 2017).

Özmete, E. (2004). Ailelerin öznel refah (subjective well-being) düzeylerine ilişkin bir değerlendirme (An assessment of families subjective welfare levels). Aile ve Toplum (Family and Society Journal), 2(6), 23-31.

President's Advisory Council on Financial Literacy (PACFL) (2008). 2008 Annual Report to the President. [Online] Available: http://www.treas.gov/offices/domestic-finance/financial-institution/fineducation/council/index.shtml. (February 06, 2017).

Raijas, A. (2011). Money management in blended and nuclear families. Journal of Economic Psychology, 32, 556 - 563.

Sevim N., Temizel, F. \& Saylır, Ö. (2012). The effects of financial literacy on the borrowing behaviour of turkish financial consumers. International Journal of Consumer Studies, 36(5),573 - 579. Son erişim tarihi: 13 Nisan 2016

Shim, S., Xiao, J., Barber, B. \& Lyons, A. (2009). Pathway to life success: a conceptual model of financial well-being for young adults. Journal of Applied Development Psychology, 30:708 - 723.

Sumarwan, U. \& Hira, K.T. (1992). Credit, saving and insurance practices influencing satisfaction with preparation for financial emergencies among rural households. Home Economics Research Journal. 21(2),206 - 227.

Temizel F. \& Bayram, F. (2011). Finansal okuryazarlık: anadolu üniversitesi iktisadi idari bilimler fakültesi öğrencilerine yönelik bir araştırma (Financial literacy: An examination of anadolu university faculty of economics and administrative sciences students ). Cumhuriyet Üniversitesi İktisadi ve İdari Bilimler Dergisi, 12(1),73- 86.

Temizel, F. (2010). Mavi yakalilarda finansal okuryazarlik (Financial literacy in blue catches). İstanbul: Beta Basım Yayım Dağıtım A.Ş.

Terzioğlu, G.R. (1990). Ailenin ekonomik faaliyetleri (Economic activities of families). Türkiye Aile Yıllığı. (Turkey Family Yearbook). Başbakanlık Aile Araştırma Kurumu Yayınları, Yayın No:10 Ankara. Ofset Repromat. Sayfa:90 -94.

Turkish Statistical Institute (TSI) (2010). Household Labor Force Survey [Online] Available: http://www.tuik.gov.tr/ (March 03, 2017).

Van Rooij, M., A. Lusardi, A. \& Alessie, R. (2011). Financial literacy and stock market participation. Journal of Financial Economics, 101(2), $449-472$.

Wagner, J. (May 2015). An analysis of the effects of financial education on financial literacy and financial behaviours. [Online] Available: http://digitalcommons.unl.edu/ (January 22, 2017). 